\title{
PSYCHOLOGICAL FEATURES OF CONFLICT IN THE SYSTEM OF MODERN RELATIONS BETWEEN RUSSIANS AND UKRAINIANS
}

\author{
Serhey Harkavets \\ Chair of Psychology, Volodymyr Dahl \\ East Ukrainian National University \\ 59-A Prospect Center, Severodonetsk, Ukraine, 093400 \\ sagark@mail.ru
}

\begin{abstract}
In the article are considered the special features of relations between Russians and Ukrainians in the context of conflict, determined by the different attitude to the world integration processes. There was made an attempt of socio-psychological analysis of idiosyncrasy as the specific psychological state of individual, connected with rejection of everything that does not correspond to its world picture. There was determined that at the individual level idiosyncrasy is caused by the system of socio-psychological influences, that lower the abilities to critical thinking of individual, level the satisfaction of its need for comfort and safety. At the mass level idiosyncrasy is installed by the emotional background factors that condition the non-acceptance of the others' preferences and emotional manifestations, connected with these preferences, in the sign and symbolic form.

There were analyzed the causes and conditions of psychological incompatibility of Russians and Ukrainians, factors that influence installation of rejection and non-acceptance. There were accented the motivational aspects of life activity, interests, social sets and value orientations of Russians and Ukrainians, that are the most relevant constructs of their psychological incompatibility. There was considered the role of television as the most effective mass media that form the "enemy image" in the consciousness of audience, the uncompromising sets of idiosyncrasy character. There was determined that individuals with the low level of critical thinking and imagination that does not draw the distinct outlines are more subjected to the destructive influence of TV-hypnosis.

There is stated that the measured information policy, where the cognitive and rational phenomena act as articulated aspects, is the effective instrument of preventing the appearance of psychological state of rejection and non-acceptance in the relations between Russians and Ukrainians.
\end{abstract}

Keywords: influence, idiosyncrasy, world image, conflict, psychological incompatibility.

(C) Serhey Harkavets

\section{Introduction}

The last events that take place in Ukraine peremptory demonstrate the abrupt opposition of the two worldview positions, two vectors of integration processes development - liberal democratic and authoritarian ones. The difference between these positions makes its more or less tolerant coexistence so impossible that many derivatives from its clash are lost in the sea of social and political casuistry. At the same time this value conflict is intensified by the resource one and, taking into account the existing world order, the role extrapolations act as the additional catalysts.

\section{Analysis of the literary data and statement of problem}

It is necessary to note, that such an opposition is not completely unique. After the Second World war Europeans faced with such conflicts in the North Ireland (A. S. Livingstone, A. Haslam, 2008) [1], in former Yugoslavia (S. Cehajic, R. Brown, E. Castano, 2008) [2] and others. But in the blustering space of rational sceneries of political elites and irrational activity of mass the motives and sets of the persons, who are not yet "infected" with political and national idiosyncrasy, who did not yet form the complexes of an acute rejection and non-acceptance of alien and strange, go at the first plan. As it is well known, idiosyncrasy (from Greek í $\delta$ เo $\varsigma$ - original, specific, excep-

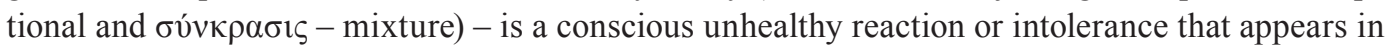
some people on irritants, that do not cause such phenomena in the others. This is heightened sensitivity of individual to the certain (sometimes objectively insignificant) effects that cause emotional discomfort [3]. In the base of this state is heightened sensitivity (sometimes innate, sometimes 
acquired) of the vegetative nervous system to the certain (most often food) irritants. Idiosyncrasy appears at the first contact with influence agent that is why it is qualitatively differ from allergy. Its main signs are head ache, respiratory, digestion, metabolism and so on disorders.

In psychology idiosyncrasy is metaphoric symbol of psychological incompatibility or intolerance between certain people. In general it is unusual human state, the attitude to the certain objects, things, views, tests and so on, when takes place aversion and non-acceptance. For example, it is well known, that W. Goethe was irritated by the people in glasses, V. Nabokov hated Freudianism. There is also distinguished emotional (intolerance to own and others' emotions) and cognitive (non-acceptance of knowledge) idiosyncrasies. And in the certain sense it is possible to say about idiosyncrasy of test preferences between parents and children, city and village dwellers, gender and ethnic (national) groups.

Taking into account the long and bloody conflict in the South-East of Ukraine that already went far beyond the region (O. Jonsson, R. Seely, 2015) [4] the problem of formation of psychological rejection or idiosyncrasy in relations between Russians and Ukrainians becomes urgent. And if for Russians it is the cute non-acceptance of all Ukrainian (language, history, national symbols, territory and so on), for Ukrainians it is non-acceptance in the concentrated form of all that is connected with so called "Russian world". The breaking out political and economic opposition, information war and awkwardly covered but armed fight between them (generally called hybrid war) lead not only to strengthen of psychological rejection but also to the appearance of pathological idiosyncrasy complex at both individual and international levels.

\section{Aim and tasks of research}

To consider the psychological installations that take place in the system of modern relations between Russians and Ukrainians and disclose the main content of its conflict on the base of formal analysis of the idiosyncrasy phenomenon.

\section{Definition and explication of the notion}

Idiosyncrasy as the subjective reaction of aversion to the external stimuli can be rather easily explicated on the concrete examples. Fox example, many people cannot stand the gritting of iron on the glass or indistinct interlocutor's speech. But psychological content of this notion much more deep, and if we say about interpersonal or intergroup relations, there takes place the conscious psychological incompatibility of interaction subjects. For understanding the main essence of psychological incompatibility that in its extreme manifestations is converted into idiosyncrasy, it is necessary to answer the question, what is compatibility.

Compatibility is an optimal combination (likeness or complementarity) of psychic qualities, value orientations and activity ways of the interaction subjects [3]. The objective compatibility factors are the physiological human features (appearance, temperament and so on), its intellectual development and physical conditions. The subject ones are: the place in social environment or group (social status, role and so on); economic state (material prosperity, financial independence and so on); cultural and educational level; worldview and religion. In the first case we can say about psychophysiological compatibility (coordination of emotional and behavior reactions, synchronization of the speed of activity) and in the second one - about socio-psychological one (community of needs, interests, social sets and value orientations).

Considering the relations between Russians and Ukrainians, it is possible to suppose, that psychophysiological polarities between them are absent or irrelevant. At the same time we consciously do not take into account differentiated parameters in separate ethnic groups that Russians and Ukrainians consist of because the correspondent distinction is absent for the present time in social and socio-psychological inquiries. That is why the words "Ukrainians" and "Russians" in title and in further text indicate the citizenship and not national identity, and as far as both countries are inhabited by the people of different nationalities, including whose who were born in the mixed families, it is a question of self-determination.

We accent the socio-psychological compatibility with the domination of subject aspects. It is a category of higher level and it is connected with formation of subject's attitude to the surrounding 
world. Strictly speaking, this is the source of problem of appearance of psychological rejection of Ukrainians by Russians and vice versa.

\section{Socio-psychological analysis of the problem}

First of all, the difference of needs of Russians and Ukrainians has both evident and hardly visible outlines. If we consider this problem in categories of A. Maslow pyramid of needs [5], we can see that the need for safety in Russians is satisfied less than in Ukrainians. It is proved by the fact, that Russia permanently "gets up from its knees", militarizes (the war budget of 2015 year - $35 \%$ or $12 \%$ from GDP), protects the "Russian world" (for example, creation of fictional Newrussia), escalates tension with the neighboring countries (Georgia, Ukraine, Baltic states), creates the "enemy images" ("fascists", "jewbanderians") and so on.

Ukrainians also have problems with satisfying the need for safety (the last events clearly prove it), but it is Ukraine that refuse the nuclear arm and received for it the guarantees of its safety and inviolability of boundaries from the leading world states, including Russian Federation. Ukrainians have the more need for affiliation that is clearly proved by their striving for integration in European community (events of the end of 2013, beginning of 2014 years). It is understood, that problem is considered at the social level and it would be unreasonable to compare these indicators with individual characteristics of the concrete persons. But information field where live the ones and the others waters down the existing phenomenological boundaries and the transfer becomes not so doubtful.

The difference of interests or emotionally saturated subject's direction on the important objects also determines the different activity of Ukrainians and Russians. So, the multi-vector of interests makes them incompatible at attainment of the socially meaningful aims. For Russians - it is the solution of most important task - conservation and expansion of the "Russian world", and for Ukrainians, first of all, the intention to keep their own national identity.

The difference of social sets of Russians and Ukrainians is that the certain actions with the concrete social objects are mutually exclusive for them. Russians product imperial ambitions connected with their "great past" and the aspiration for being the part of no less "great present" at cognitive, affective and operational levels. It is undoubtedly, as John Mole just notes it, the history of victories and achievements, large territorial acquisitions, countless natural resources form in the consciousness of Russians the world picture where Russia is the superstate [6].

Ukrainians who had not their own statehood in past (with insignificant exclusion) want to fix it in territorial boundaries and occupy the worthy place among European countries. At the same time they produce national idea at the sense level (language, traditions, symbols), but unfortunately, it is hindered at operational level by the imperfect structure of Ukrainian society (deep social exfoliation, week political elites, bureaucratization, corruption and so on).

We think that value orientations are the most relevant constructs of socio-psychological incompatibility between Russians and Ukrainians. The substantial direction of activity of them is not simply different; it is confronting and mutually exclusive. Russians mainly profess paternalism that is concentrated expression of their whole value system (safety and protection, conservatism, power, dependence, conformism, subjecting, continuity and so on) and they are not inclined to the values of novelty, creation and freedom [7]. Most of them cannot stand passionarity. Even when there was place for it, with time all came back to the usual and passionarity became to be considered as psychic disease that few individuals suffer from.

Ukrainians in general are oriented on the other values although it is noted that the difference in axiological parameters depending on region. But as we already said, in this socio-psychological analysis we deliberately do not single out the separate ethnic groups among Russians and Ukrainians. Let us add that we are based on the presupposition that the nation that lives within the boundaries of one state must be considered as the rorganic whole, despite the native language, religion, culture and traditions. If we decide to carry out the differential analysis first of all it would deal with Russians because polyethnism in Russia is more evident than in Ukraine.

As researchers note, in Ukrainians predominate orientation on the values of freedom, dignity, autonomy, individualism and so on [8]. At the same time it must be noted, that among Ukrai- 
nians take place paternalist aspects in the value priorities (for example, so called hetmanship) but according to history, Ukrainians always can overthrow anybody who does not justifies its social expectations. Russians are less able to it because they have an expressed dispositional set of paternalism and most of them think that "every power was given by God, and it is does not benefit to resist it". This tradition is very strong in Russian socio-cultural space and that is why most of them consider all revolutions as an export of somebody's evil will [9].

The values system is the core of personal worldview and it is the very reflection of all purposeful activity of individuals, separate ethnoses and national groups. And in the conditions of globalization and intensification of information expansion individuals become to be completely dependent from the mass media that not only set the value priorities but also propagate the absolute value of acceptance or non-acceptance of the others. So, all that we can observe last time is the product not only of value dispositions of Russians and Ukrainians, formed in the process of life activity, but also of the negative value constructs, deliberately created by mass media, that can be focused in the unhealthy idiosyncrasy states.

Undoubtedly, that Russian TV, the so called "second nuclear button" plays the main role in the process of humiliation of Ukrainians. Specialists on TV studies maintain the really existing phenomenon of "TV-hypnosis" [9]. Watching TV, person as if fall in some kind of hypnosis, is fascinated by the moving picture on the television screen like people who look at stars or campfire. As researchers note: "As the results of such effects are formed not the rational and substantiated views but the faith or fear that does not need any serious argumentation. The receptivity to such psychological effects is determined by the specific state of human consciousness when criticality of assessment of information and the level of conscious control are essentially lowered" [9]. And when the picture is "madly" negative, when person seating in front of the screen as if "takes root in the chair" or abruptly jump from it, the self-assessment is lowered and the fight for it is consequently intensified, the level of negative emotions, self-doubt, neurotization are raised and the ability to logical analysis is decreased. It is worth noting, that the TV-hypnosis level in Russians can be intensified by the peculiarities of their imagination. As A. I. Solzhenitsyn noted, the Russians' does not draw the distinct outlines, there are dreams instead of understanding of reality [10].

But as the any phenomenon the formation of "enemy image" has its averse-reverse manifestation [11]. The negative creation on the one side favors the positive creation on the other one. In this case positive is included in the fact that surplus hatred replication results in boomerang effect that is rejection of information when there is surplus of it and when it becomes destructive for the subject of perception. So, the individual is able to reduction that takes place when the lie is not simply large (quantitative parameter) but when it completely substitutes the truth (qualitative parameter) and he is forced to disclaim the obvious facts. But in this conflict space can be interlaced his needs, interests, social sets and values that is all factors that can generate intrapersonal conflict. Solving this conflict, individual gets rid of constructs that generate it and in such a way as if unseal the "abscess" of destructiveness. But if it does not take place because of physiological, intellectual, cultural, educational and other limitations, intrapersonal conflict will generate the external reactivity to the certain objects and involve individual in the state of idiosyncrasy. In such subjects this state will be caused by external stimuli that initially were annoying or caused aversion and designation or threatened the life. As for concrete individuals - there are manifestations of the stable psychological incompatibility that are difficult to overcome.

The same state with catastrophic speed begins to appear and develop among Ukrainians. Depersonalization of Russians is based on its stigmatization as "moskal", "vatnik", "rushist" and so on. At the same time there takes place the one essential difference: Ukrainian mass media do not produce for now such aggression to Russians as the Russian propagandists. It can be explained by the fact that physical collision evidently takes place not with Russia as such but with pro-Russian militants and mercenaries of the different ethnic origin (Russians, Chechens, Ossetians, Abkhazians, Serbians and so on). But it is undoubted, that at the open armed conflict between Ukraine and Russian Federation the depersonalization and dehumanization of all Russian would become prerogative of not only Ukrainian patriots but also people who still keep the certain tolerance to Russians for today. 
It is worth noting that conserved aversion in relations at the personal level is not so deep and fatal than at the intergroup or interethnical ones [12]. And it is well known from the psychology of conflict the cruelest opposition is the one of relatives or close people [13]. Today many Russians who did not find mutual understanding with relatives from Ukraine break the close relation as, in fact, the Ukrainians themselves who reject them for the indulgence in the aggressive plans of Russian leaders. We can see that nothing harden people more than polarity of political views. This situation took place in Ukraine in 2004-2005 when Ukrainians were divided into "orange" and "white-blue". The split took place in many Ukrainian families and it was deepen so much that blood relatives and relatives by marriage already kill one another.

Earlier we tried to analyze the relations between Russians and Ukrainians in the context of installation of mutual offence and came to conclusion that it is manifested at two levels. At the first one Russians (like a refused admirer) are discontent because ungrateful Ukrainians want to "throw" them, "go to the other", become the part of Europe instead of the "Russian world" that is considered as treachery. At the second level Ukrainians feel humiliation of their dignity because somebody misappropriated the right to make their crucial decisions instead of them [14].

The idiosyncrasy manifestations at the group or mass level have one peculiarity - the complete absence of understanding (cognitive substantiation) of the own negative attitude to the representatives of other group. For example, at individual level many people know what are the differences and the common features between scout and spy but in the mass consciousness such differentiation is absolutely impossible. The image of Americans is also the model one in the consciousness of Russians and pro-Russian Ukrainians. The post-Soviet imperial orientation, unfortunately, did not lose its dominance and it is the main cause of the fact that in the acute moments of conflict the hostility between Soviet (that is Russian) and pro-western (pro-American, pro-European) arises and acts in the mass consciousness of post-soviet people. It is necessary to accept, that system of soviet education that still present in general educational institutions has a negative influence of the formation of worldview of the young generation. In fact it is the manifestation of incompatibility of the "Russian world" and the world of universal values. Ukraine want to become the part of united Europe but most likely the pay for it will be the national idiosyncrasy to all personified by the "Russian world".

The significant feature of it is the service "rest without Russians" recently appeared in tourist agencies that became possible just as the result of Ukrainian need not to contact with representatives of Russia at rest. And in Ukrainian super-markets the customers actively became to refuse products produced in Russian Federation. At the same time at the state level are introduced limitations in access to the films, TV-programs produced in Russia.

\section{Offers and cautions}

All aforesaid actualize the problem of search for the measures for overcoming idiosyncrasy sets in relations between Russians and Ukrainians. Such measure is the realization of system of socio-psychological influences where the main place will be occupied not by the emotional-background constructs (propaganda, hypnosis, infection) but by the rational and cognitive phenomena (arguments, facts, persuasion). But for its realization it is necessary to carry out the complete revision of information policy that, unfortunately, functions as propaganda for today. The one more step can be the information expansion analogous to the one of soviet period when million soviet people leaned to their radios, listening the "Voice of America" or "Radio Freedom". At the same time for today Internet is the powerful mean of informational influence and in conditions of the free access (free WiFi) can level the existing informational limits. But do not forget, that mass media can also condition idiosyncrasy in people, if it becomes the cause of their emotional discomfort. Today there are people who do not look informational TV-programs and ignore the mass media as a whole.

\section{Conclusions}

1. Political, economic, information and war confrontation (hybrid, non-linear opposition) between Russians and Ukrainians generate emotionally negative and cognitive-destructive sets that can become the base of formation of the stable idiosyncrasy complex in their future relations. 
At individual level such idiosyncrasy is generated by the system of socio-psychological influences that lowers the personal abilities to critical thinking (this is cognitive idiosyncrasy that is articulated first of all), levels the satisfaction of need for comfort and safety, generates non-acceptance and rejection of all that is not included in the personal mental world picture. At the mass level idiosyncrasy is installed by the emotional background factors that in sign and symbolic form condition the non-acceptance of the others' preferences and emotional manifestations connected with it. The obtrusion of the negative image of other or others by the influence agents, first of all, by the mass media generate in the mass consciousness the stable emotional sets of destructive character.

2. The forming idiosyncrasy in relations between Russians and Ukrainians does not have objective causes; it is imposed by the adventurist political subjects, so the measured information policy, where cognitive and rational phenomena must be the articulated aspects, can become the barrier to such state.

3. The different political and economic vectors of development of Russia and Ukraine are not the fatal causes of intensification of hostility and confrontation between it. In the modern globalized world it is self-isolation of the country and the system of socio-psychological effects that are the main determinants of idiosyncrasy at intergroup and international levels. The subjects of policy, who try to form the images of hated enemies in the mass consciousness, to create hostility and irreconcilability between nations, make the great mistake and crime which results can be catastrophic. Unfortunately, there are a lot of such examples in the human history.

\section{References}

[1] Livingstone, A. S. Haslam, A. (2008). The importance of social identity content in a setting of chronic social conflict: Understanding intergroup relations in Northern Ireland. British Journal of Social Psychology, 47 (1), 1-21. doi: 10.1348/014466607X200419

[2] Cehajic, S., Brown, R., Castano, E. (2008). Forgive and Forget? Antecedents and Consequences of Intergroup Forgiveness in Bosnia and Herzegovina. Political Psychology, 29 (3), 351-367. doi: 10.1111/j.1467-9221.2008.00634.x

[3] Enikeev, M. I. (2008). Psichologicheskiy enciklopedicheskiy slovar. Moscow: Prospekt, 560.

[4] Jonsson, O., Seely, R. (2015). Russian Full-Spectrum Conflict: An Appraisal After Ukraine. The Journal of Slavic Military Studies, 28, 1-22. doi: 10.1080/13518046.2015.998118

[5] Maslow, A. (2007). Motivation and personality. Sankt-Peterburg: Piter, 352.

[6] Mole, J. (2006). Osobennosti nacionalnoy psichologii narodov novoy Evropy: biznes, obschenie, uspex. Moscow: Astel, 381.

[7] Magun, V., Rudnev, M. (2013). Basic Human Values of Russians: Both Different from and Similar to Other Europeans. SSRN Electronic Journal. doi: 10.2139/ssrn.2317178

[8] Kisarchuk, Z. G., Grebin, L. O., Gurleva, T. S. (2012). Siciokulturni chinniki stanovlennya suchasnoy paradigmy psichoterapevticheskoy dopomogi osobistosty. Kirovograd: Imeks-LTD, 276.

[9] Bogdanov, E., Zazikin, V. (2003). Psichologicheskie osnovy «Pablik rileshnz». Sankt-Peterburg: Piter, 208.

[10] Solzenicin, A. I. (1998). Rossiya v obvale. Moscow: Russkiy put, 206.

[11] Harkavets, S. O. (2010). Socialno-normativniy konformizm osobistosti u psychologichnomu vimiri. Lugansk: Noulidg, 343.

[12] Taras, R. C., Rajat, G. (2015). Understanding Ethnic Conflict. Routledge, 336.

[13] Bogdanov, E. N., Zazikin, V. G. (2004). Psychologuya personality v konflikte. Sankt-Peterburg: Piter, 224.

[14] Harkavets, S. A., Yakovenko, S. I. (2014). Obida i ee instalyaciya v kontekste rossiysko-ukraiskix otnosheniy. Fundamentalnie i prikladnye issledovaniya v praktikax veduchix nauchnyx shkol. Available at: http://fund-issled-intern.esrae.ru/4-47 